\title{
ENGLISH WITH FLYING COLORS: THE AVIATION ENGLISH AND THE INTERNATIONAL CIVIL AVIATION ORGANIZATION
}

\begin{abstract}
There are several reasons for the English language to become lingua franca of aviation including some historical turning points for the world aviation and some specific linguistic features of the language itself. This paper aims to firstly present a short, yet interesting history of implementation of English as standardized language for aviation. It will provide introductory historical background, establishment of arguments necessary for standardization and leading to the implementation of the Language Proficiency Requirements (LPRs) within the International Civil Aviation Organization (ICAO). It will then provide an overview of the ICAO's actions to support its members states in implementation of the English language standards for aviation and try to evaluate the effects based on the powers granted to the Organization. Such evaluation will be presented in the comparative perspective with the powers and instruments used within the European Union to achieve the same goal - standardization of the aviation English.

Keywords: International Civil Aviation Organization, Aviation English, ATC English, Language Proficiency Requirements
\end{abstract}

\section{Introduction and Historical Perspective}

Despite earlier attempts to use the airspace as a travelling space, it was the 1903 "Flyer I" seconds-long flights performed by the American brothers - Wilbur and Orville Wright in Kitty Hawk, North Carolina which marked the very beginning of the history of aviation and changed the world (Wagner, 1970:2, Dempsey, 1992: 1). The development of air industry was powered by the military engagement in both world wars. By the end of the World War II, it was clear that the post-war transportation era will be dominated by the use of aircraft.

In 1944, the President of the United States of America invited representatives of over 50 states to gather in Chicago and discuss the future of legal 
regulations for the international civil aviation. The conference was clearly dominated by the American and British delegations and their actions (as both countries at the time had the best negotiating position in terms of the aircraft operations in the world) with strong involvement of Canadians and Australians. The four nations' native language is English.

During the 1944 conference the Convention on International Civil Aviation (the Chicago Convention or the Convention) was signed and, among other regulations, it established the International Civil Aviation Organization (ICAO, with presently 191 member states) to maintain safe and secure use of civil aircrafts around the globe (art. 43-44 of the Chicago Convention). It is worth to note that the original text of the Chicago Convention was prepared and accepted in the English language only, which was unusual for international documents of such importance (Fitzgerald, 1970: 364-371).

The above presented circumstances might be considered the first, historical arguments for the use of English language as language of aviation. For decades to follow however, it was only the practice of the states involved and internal regulations recommending the airport staff, the members of the crew in cockpit and especially the pilots and air traffic controllers (ATCs) to use English for communication purposes. The debate concerning the suitability of the English language for the air communication could justifiably continue due to the specifics of the language (given the phraseology problems for example). Nevertheless, the worldwide acceptance of this language for flying has become a fact (Seiler, 2009: 44). Under the auspices of ICAO, English eventually became standardized language to be used "in the skies" as one of the necessary tools for safe flights.

In the presented article the problems leading to such standardization are introduced followed by the attempts of the ICAO to solve them and to provide member states with effective tools supporting implementation of the established standards. An attempt to evaluate the effectiveness of the ICAO's work is then followed by the example of the European Union and comparative analysis of the possibilities for language standards implementation deriving from the Union's powers and laws binding upon its member states.

\section{ATC-English Problems Identified}

Series of fatal air accidents in which the lack of proficiency in English had been identified as a contributing factor, led to series of ICAO decisions concerning the improvement of English for pilots and air traffic controllers involved in international operations. 
The most known are the accidents in the 1970s, opening with the Tenerife Airport disaster in 1977, the deadliest aircraft crash in the history of civil aviation with total of 583 victims. Miscommunication between the pilots of two planes and the traffic control was one of the investigated reasons for the tragedy. The PSA Flight 182 accident in the air followed in 1978 with 144 victims. However, the series that directly led to the international recognition of the need for standardized airspeak occurred in the 1990s. The Avianca Flight 52 crashed in 1990 with 73 killed, the American Airlines Flight 965 hit a mountain killing 159 people, the most tragic Charkhi Dadri mid-air collision in 1996 left 351 dead and finally the 1997 accident of Garuda Indonesia Airlines Flight 152 added 234 victims. In all cases language miscommunication played an important role and was confirmed as one of the reasons or even the main reason causing tragedy. Extensive research has been carried dedicated to the above and many other air accidents, with special emphasis on the language miscommunication between the pilot and air traffic controllers as one of the factors leading to the crash (Cookson, 2009: 22.1-22.14; Garzone et al. 2010: 217-219; Tajima, 2004: 451-470; Jones, 2003: 233-48; Breul 2013: 71-84).

The language used between the pilot and the air traffic controller is known as ATC-English, which on every linguistic level differs from natural English and falls under the ESP (English for Specific Purposes) category in linguistics (Breul, 2013: 74). As Moder and Halleck summarize, the ATC-English "is used for a very restricted set of functions and has a prescribed phraseology with reduced syntax and vocabulary for routine actions. The communication involves extensive shared information concerning the aircraft in the area, the parameters of the airport or airspace, and the expected actions at particular points in the flight" (Moder and Halleck, 2009: 25.2). The most popular examples of the air speak are popularized even by film productions. "Affirm" for "yes", "Negative" for "No", "Cleared" for "Authorized, Go ahead" symbolize the uniqueness of the language used in the air.

It should be noted here, that English used in the cockpit communication between the crew members, also known as Cockpit English has its own specifics and will be left outside the scope of the paper (for analysis of the Cockpit English issues see: Nevile, 2004).

The research carried out by the official government agencies seems to bring similar results. In 1998 the United States' Federal Aviation Administration prepared the report on pilot-controller communication errors based on the reports submitted by the pilots, controllers and others to the Aviation Safety Reporting System (ASRS) on events possibly affecting air safety. 
As a result, communication errors were divided into three categories: 1 . absence of pilot readback (most of the times pilot merely acknowledged the clearance that she/he misunderstood) accounting for $47 \%$ of the analyzed errors, 2. readback/hearback error (where pilot reads back a clearance incorrectly and the controller fails to catch the readback error) accounting for $25 \%$ of analyzed errors, 3 . hearback type II errors (where pilot correctly repeats the clearance that was issued, but the controller fails to notice that this clearance was not the intended one) accounting for $18 \%$ of the analyzed errors. The remaining 10\% were errors of other nature such as pilot misunderstanding the clearance (Pilot-Controller Communication Errors 1998: 4).

To no surprise, the more air transportation is performed, the statistics and variety of air accidents grow. Safety of air travels depends, among other factors, on clear and errorless communication between the pilot of the aircraft and air traffic controller, occurring entirely over radio frequencies with not face-to-face interaction (Moder, 2014: 228).

\section{The ICAO Standards and Language Proficiency Requirements}

One of the powers vested to the Council of the International Civil Aviation Organization (a permanent organ composed of 36 member states and functioning as an executive governing body of the ICAO) is to adopt international standards and recommended practices (SARPs) in form of Annexes to the Chicago Convention (art. 54(l) of the Convention).

The adoption and required amendment of already existing standards and practices aim to achieve highest possible degree of uniformity in regulations, procedures and organization relating to the use of air and concerning the safety, regularity and efficiency of air navigation (art. 37 of the Convention). The Convention provides an open catalog of fields in which SARPs should be adopted and the top of the list belongs to the "communications systems and air navigation aids" (art. 37 (a) of the Convention).

In other words, the ICAO issues standards and practices addressed to all member states of the organization. These states are encouraged to implement them in their laws and procedures so the air carriers around the world use uniform procedures and systems. However, the implementation of SARPs is not mandatory under the Chicago Convention. Member states are only obliged to notify the ICAO about the departures from adaptation of the SARPs (art. 38 of the Convention). This rule is regarded a legally binding obligation of the contracting states to the Chicago Convention (Weber 2007: 34). Effectiveness of the uniformity of air navigation depends on the 
will of sovereign states based on the perception of mechanisms leading to safe and secure air travels.

Since 1944, total of 19 Annexes have been adopted by the ICAO covering a wide range of airspace issues including: personnel licensing, rules of the air, meteorological service, operation of aircraft, aeronautical communications, aeronautical information services, security, safety management and other. The Air Navigation Commission established by the Council as the main technical organ of the ICAO is responsible for the preparation of amendments and modifications to the Annexes and their recommendation to the Council (art. 57 of the Convention). The ICAO runs audit programs of the safety oversight systems and monitoring of the aviation security performance in all its member states (Weber, 2007: 23).

The tragic air accidents of 1990s motivated the ICAO to specifically address the language issues. During the 32nd Session of the ICAO Assembly in September 1998 the decision was made to address the problem of language requirements for pilots and air traffic controllers based on the facts established in the major recent air accident investigations indicating lack of proficiency and comprehension of the English language by flight crews and air traffic controllers as a contributing factor. Relevant provisions of the selected Annexes to the Chicago Convention, with special emphasis on two of them - Annex 1 (Personnel Licensing) and Annex 10 (Aeronautical Telecommunications) were to be strengthened "with a view to obligating Contracting States to take steps to ensure that air traffic control personnel and flight crews involved in flight operations in airspace where the use of the English language is required, are proficient in conducting and comprehending radiotelephony communications in the English language" (Assembly Resolution A32-16).

It took another five years before the necessary amendments to the Annexes were prepared by the Air Navigation Commission. As a result, in March 2003, the Council adopted proper amendments with set of SARPs addressing language requirements for pilots and air traffic controllers. Two most important amendments included: Amendment 164 to Annex 1 stipulating that they should speak and understand the language used on radiotelephony communications to the level specified, which is Level 4 - the operational level considered the safety threshold (Annex 1: Rec 1.2.9), as well as Amendment 78 to Annex 10 stating that "if a pilot and an air traffic controller do not speak a common language, the default language is English and that the English language is shall be available, on request from any aircraft station, at all stations on the ground serving designated airports and routes used by international air services (Annex 10: Rec 5.2). 
As a result then, all pilots and controllers involved in international operations who do not share a common language must communicate in English and thus their level of English language proficiency has to be stated on their licenses.

The set of holistic descriptors (included in Appendix to Annex 1) together with the ICAO Rating Scale (included in Attachment to Annex 1) constitute the ICAO Language Proficiency Requirements (LPRs).

The LPR Manual underlined that "while the ICAO Language Proficiency Requirements were developed for use in assessing language proficiency in all languages used for radiotelephony communications, not just in the English language, much of the focus of this manual is on English language training issues, as this is the area in which most States and aircraft operators require specific guidance" (Manual 2004: vii).

As Moder and Halleck note, the tension between the use of standard phraseology and plain language is an ongoing issue in the aviation community. Operational training facilities and international policies emphasize that standard phraseology should be used in all cases, and that the use of plain language should be restricted only to those situations in which there is no standard phraseology (Moder and Halleck, 2009: 25.3). In the real life situations, there are plenty of moments (such as system failures, passenger illness, deviated flights, bad weather conditions, etc.) where standardized phraseology simply cannot describe the reality and its urgent needs (Shawcross, 2015).

The ICAO Language Proficiency Requirements aimed to establish two major rules concerning the problem. First, a greater emphasis is placed on the importance of the use of ICAO phraseologies. Member states were to make sure that their aviation phraseology conforms to the one provided by the ICAO. Elimination of different types and versions of specific aviation phraseologies used in different regions of the world would certainly help to eliminate the danger of misunderstanding in communication. Secondly, even though the ICAO phraseology should always be used in the first place, the fluent communication in plain English is underlined as necessary and important part of air communication and "when plain language is required, it should be delivered in the same clear, concise, and unambiguous manner as phraseologies" (Manual: 2-3). The language proficiency requirements are applicable to the use of both phraseologies and plain language (Appendix to Annex 1 APP 1-1).

According to the ICAO standards, to meet the required LPRs, an applicant for a license or a license holder must demonstrate, "in a manner acceptable to the licensing authority, compliance with the holistic descrip- 
tors and with the ICAO Operational Level (Level 4) of the ICAO Language Proficiency Rating Scale" (Appendix to Annex 1 APP 1-1). "The holistic descriptors provide all-embracing characteristics of proficient speakers and establish some context for communications where the Rating Scale describes the discrete features of language use" (Manual: 2-6).

Proficient speakers prove the following characteristics: "a) communicate effectively in voice-only (telephone/radiotelephone) and in face-to-face situations; b) communicate on common, concrete and work-related topics with accuracy and clarity; c) use appropriate communicative strategies to exchange messages and to recognize and resolve misunderstandings (e.g. to check, confirm, or clarify information) in a general or workrelated context; d) handle successfully and with relative ease the linguistic challenges presented by a complication or unexpected turn of events that occurs within the context of a routine work situation or communicative task with which they are otherwise familiar; and e) use a dialect or accent which is intelligible to the aeronautical community" (Appendix to Annex 1 APP 1-1).

The ICAO Language Proficiency Rating Scale provides for 6 levels of the language proficiency (with level 1 being pre-elementary and level 6 being expert based on the description of each level in six fields: pronunciation, structure, vocabulary, fluency, comprehension, interactions). The future pilots and air traffic controllers are to be tested and confirmed with the proficiency on minimum level 4 - operational. In this level the "pronunciation, stress, rhythm, and intonation are influenced by the first language or regional variation but only sometimes interfere with ease of understanding (pronunciation). The basic grammatical structures and sentence patterns are used creatively and are usually well controlled. Errors may occur, particularly in unusual or unexpected circumstances, but rarely interfere with meaning (structure). Vocabulary range and accuracy are usually sufficient to communicate effectively on common, concrete, and work-related topics". The candidate can "often paraphrase successfully when lacking vocabulary in unusual or unexpected circumstances (vocabulary)". Further, the candidate "produces stretches of language at an appropriate tempo. There may be occasional loss of fluency on transition from rehearsed or formulaic speech to spontaneous interaction, but this does not prevent effective communication". He/she can make "limited use of discourse markers or connectors. Fillers are not distracting (fluency). Comprehension is consistently accurate in nearly all contexts and includes comprehension of linguistic and cultural subtleties (comprehension)". Finally, the future pilot of air traffic controller "interacts with ease in nearly all situations and is sensitive to verbal and 
non-verbal cues and responds to them appropriately (interactions)" (Attachment A to Annex 1 ATT A-1). The ICAO Rating Scale is provided in a table and widely used in training, testing and informative materials worldwide. It has been prepared by the group of experts in linguistics and specialists in the industry (so called PRICE Study Group) but there has been some disappointment voiced by the ESP experts regarding the limited information on the precise methodology used for the development of the scale (Knoch, 2014: 77).

\section{Implementation of the Language Proficiency Requirements by the ICAO member states on global and regional levels}

The original date for the implementation of LPRs in the ICAO member states was set for 1 January 2008. The deadline was eventually extended to March 2011 (by the Assembly Resolution A36-11 passed in 2007) as it turned out to be a very challenging task for many ICAO member states despite publishing of the ICAO's Manual on the Implementation of ICAO Language Proficiency Requirements (Abeyratne, 2012: 121). According to the ICAO, member states had troubles implementing the LPRs due to the lack of qualified personnel to evaluate the language skills and to the scarcity of dependable language testing expertise and lack of the universal system of aviation language test endorsement. The training and testing industry in aviation English remained unregulated (ICAO Journal 2013: 64-65).

There are also other problems occurring with the application of the LPRs in the member states and the case of Poland may serve as an example.

The obligation to prove the required level 4 of the English language (as requested by the Annex 1 to the Chicago Convention) has been implemented into the Polish law through the amendment of the Ministry of Infrastructure Regulation on the aviation personnel licensing of 2009 and then included into the new Regulation on the aviation personnel licensing of 2013 (Official Journal 2013, item 1077). The Australian RELTA system was used for testing and evaluation of the English language skills for pilots. The exam was free of charge for the candidates. There were however series of situations where the candidates who had failed the RELTA test would go to a specific examination place in Germany, pass the exam there (a different one - for which they had to pay but which also confirmed the level 4 requirement) and then ask the Polish Civil Aviation Authority (CAA) for the recognition of the language certificate. Such recognition is naturally allowed under Polish law (the 2008 Decree 5 of the President of the Civil Aviation Authority, 
$\S 3$ p. 4). It turned out, however, that the testing person in Germany did not have the required qualification and was forging the documents. The problem was quickly spotted and resolved by proper administrative actions toward the pilots who had been tested by the unauthorized German instructor but such situations only prove that even the candidates for pilots themselves do not pay proper attention to the fact that fluent communication in English is essential for the safety of the use of air (Kralewski, 2010).

In the 2010 Resolution the ICAO once again urged the states struggling with the implementation to provide updated implementation plans and directed the Council to monitor the status of implementation of LPRs (Assembly Resolution A37-10).

To support member states in their work on the adoption of the language standards in aviation, the ICAO has established and operates couple of projects dedicated to the assistance.

In 2006, the first Rated Speech Sample Training Aid (RSSTA) was issued under the auspices of the ICAO to provide real-life samples of the communication between pilots and ATCs to improve the training programs. The ICAO cooperates closely with the International Civil Aviation English Association (ICAEA) and, as a result, the second edition of the speech sample project was issued in 2010 (samples and detailed description is available on-line: http://cfapp.icao.int/rssta/).

In response to one of the fundamental problems in the implementation of the LPRs, that is the problem of how to evaluate the skills and how to make sure the proper rating systems are adopted (Seiler 2009: 45), the ICAO decided to establish a mechanism to provide states with impartial recommendations in the selection or development of aviation English language licensing tests that meet ICAO criteria. As a result, in October 2011, ICAO announced the introduction of the Aviation English Language Test Service (AELTS) to assess language tests in order to help its member states assess more accurately the speaking and listening ability in English of pilots and air traffic controllers (ICAO Journal 2013: 56).

The latest attempt addressing the language issues was undertaken during the 38th Session of the ICAO Assembly (in October 2013) and resulted in adoption of another Resolution - A38/8 which superseded the previous one. The Assembly repeated the urge to use the ICAO standardized phraseology in all situations for which it has been specified, provided for further support to members states which still encounter considerable difficulties in implementing the language proficiency requirements including the establishment of language training and testing capabilities. In addition, it encouraged member states to make use of the ICAO Aviation English Language Test 
Service (AELTS) to verify language testing instruments and to make use of the ICAO Language Proficiency Requirements - Rated Speech Samples training aid.

The ICAO developed a special Flight Safety Information Exchange website "to provide the aviation community with access to safety related information" (http://cfapp.icao.int/fsix/index.cfm). It provides information on the compliance with the SARPs, including the information on the implementation of the Language Proficiency Requirements. The available map with status of compliance with LPRs (based on the information voluntarily submitted by the member states) currently shows that the full process of implementation has been notified to the ICAO by the United States and Canada in North America, by Brazil and Argentina in South America, twelve countries from Africa, most of the European states and only a few in Asia.

The ICAO's attempt to standardize the use of English in air communication is not an easy task and it would be hard to call it a very successful attempt so far. Worldwide acceptance and implementation of any standards brings variety of challenges and obstacles, especially that failure to implement the proposed standards is not sanctioned in any way.

The situation looks very different under circumstances of other organizations aiming at strengthening the civil safety and security on a narrower geographical level and with use of stronger legal instruments. The European Union (EU) may serve as an excellent example. Based on the Rome Treaty provisions, the rules concerning transport within the EU may be extended to the air transport based on the legislative acts of the European Parliament and the Council (art. 100 of the Treaty on the Functioning of the European Union). As further provided in the Treaty, the secondary laws passed by the European institutions in forms of inter alia regulations and directives provide binding, direct and automatically applicable sources of law for all the twenty eight member states of the European Union (art. 288 of the Treaty on the Functioning of the European Union). The Union is then empowered with much stronger instruments necessary to provide for uniform implementation of any standards which becomes part of the EU law provisions.

In 2002 the European Aviation Safety Agency (EASA) was established as the European Union Authority for aviation safety (currently Regulation (EU) 216/2008). Based on the 2008 Regulation, the EASA is responsible for the preparation of technical opinions forming basis for the legislative proposals by the Commission, as well as for carrying out standardization inspections to monitor the application of relevant aviation legislation in the 
EU member states. EASA is also fully responsible for all types of certifications necessary for the air transportation within the EU.

While dealing with the discussed English language problems, not only has the EU adopted the ICAO standards for civil aviation but it went further. Based on the 2006 Directive on a Community air traffic controller licence (Directive 2006/23/EC), by 2010 all ATCs within the EU had to confirm their English language proficiency on the ICAO lever 4. Language proficiency on "at least an operational level of language proficiency both in the use of phraseologies and plain language" for all pilots is required by the 2011 Regulation on laying down technical requirements and administrative procedures related to civil aviation aircrew (Commission Regulation (EU) 1178/2011).

The implementation of the directives within the twenty eight member states of the EU has proved to be more effective, but it also faces some practical problems resulting in dynamic amendments of the original laws regulating the licensing (the 2011 Commission Regulation has been amended four times, with latest amendment in 2015 by Regulation (EU) 2015/445). Still, because of the specificity of the relations between the EU and its member states and the binding force of the EU laws, the implementation of the ICAO language standards within the EU has been achieved much more successfully and uniformly throughout the Union. The European Commission has dedicated generous funds to the development of aviation English projects that would help strengthening of the civil aviation within the European Union, including, for example, designing a multimedia course for those who plan to work in European airports as the ground staff (Cutting, 2011: 3-4).

\section{Conclusions}

Despite undeniable arguments that high proficiency of standardized English is necessary for the safety of aviation, the competences of the International Civil Aviation Organization are not powerful enough to provide for the uniform use of the proposed language standards. Since the ICAO may only encourage its member states to adopt the LPRs, with no binding force of its resolutions, the process is long and not satisfying enough. Much more effective implementation has been achieved within the European Union, due to the powers of the Union's institution to pass law binding its member states. Member states of the ICAO may ignore or partly respect the standards issued by the Organization with no negative consequences involved, while member states of the Union in such situations are faced with regular 
responsibility including the action against them in the Court of Justice and possible penalty and lump sum payments as a sanction for the failure to fulfill the obligations included in the Treaty (art. 259 and 260 of the Treaty on the Functioning of the European Union).

\section{R E F E R E N C E S}

Abeyratne R.I.R. (2012). Air Navigation Law. Heidelberg Dordrecht London New York: Springer.

Breul C. (2013). Language in aviation: The relevance of linguistics and relevance theory, LSP Journal, 4, 1, 71-86.

Cookson S. (2009). Zagreb and Tenerife: Airline Accidents Involving Linguistic Factors, Australian Review of Applied Linguistics, 32, 3, 22.1-22.14.

Cutting J. (2012). English for airport ground staff, English for Specific Purposes, 31, 3-13.

Dempsey P.S. (1992). The State of the Airline, Airport and Aviation Industries, Transportation Law Journal, 21, 1,129-214.

Fitzgerald G.F. (1970). The Development of the Authentic Trilingual Text of the Convention on International Civil Aviation, The American Journal of International Law, 64, 2, 364-371.

Garzone G., Catino M., Gobo G., Bait M., Catenaccio P., Degano Ch., Rozzi S. (2010). Towards and Integrated Model for Understanding of Communication Failures in Aviation Accidents: Tenuous Identities under Pressure. In G. Garzone, J. Archibald (Eds.), Discourse, Identities and Roles in Specialized Communication (pp. 209-244). Bern: Peter Lang.

Jones R.K. (2003). Miscommunication between pilots and air traffic control, Language Problems 83 Language Planning, 27, 3, 233-248.

Knoch U. (2014). Using subject specialists to validate an ESP rating scale: The case of the International Civil Aviation Organization (ICAO) rating scale, English for Specific Purposes, 33, 77-86.

Kralewski P. (2010). ICAO Level 4 - prawdy i mity o egzaminach z języka angielskiego w ULC. Wywiad z Katarzyną Krasnodębskac - Rzecznikiem Polskiego Urzędu Lotnictwa Cywilnego (ICAO Level 4 - truths and myths about the English exam at PCAA. Interview with Katarzyna Krasnodębska - the Spokeswoman for the Polish Civil Aviation Authority) 18.11.2010, Retrieved August 28, 2015 from: http://dlapilota.pl/wiadomosci/dlapilota/icao-level4-prawdy-i-mity-o-egzaminach-z-jezyka-angielskiego-w-ulc.

Moder C.L. (2014). Aviation English. In B. Paltridge, S. Starfield, The handbook of English for Specific Purposes (pp. 227-242). Chichester: Wiley Blackwell.

Moder C.L and Halleck G.B. (2009). Planes, politics and oral proficiency. Testing international air traffic controllers. Australian Review of Applied Linguistics, 32, 3, 25.1-25.16. 
Nevile M. (2004). Beyond the Black Box: Talk-In-Interaction in the Airline Cockpit (Directions in Ethnomethodology and Conversation Analysis). Aldershot: Ashgate Pub Ltd.

Seiler W. (2009). English as a lingua franca in aviation, English Today, 25, 2, 43-48.

Shawcross P. Social, safety and economic impacts of global language testing in aviation, Aviation English Academy. Retrived September 1, 2015 from https:// aviationenglishacademy.com.au/resources/social-safety-and-economic-impa cts-of-global-language-testing-in-aviation/

Tajima A. (2004). Fatal miscommunication: English in aviation safety, World Englishes, 23, 3, 451-470.

Wagner W. J. (1970). International Air Transportation as Affected by State Sovereignty. Bruxelles: Etablissements Emile Bruylant.

Weber L. (2007). International Civil Aviation Organization. Introduction, Alphen aan den Rijn: Kluwer Law International.

\section{Legal sources:}

The ICAO legal sources (available through the ICAO website: www.icao.int):

Convention on International Civil Aviation, ICAO Doc 7300

ICAO Assembly Resolution A32-16, Proficiency in the English language for radiotelephony communications (2003)

ICAO Assembly Resolution A36-11, Proficiency in the English language used for radiotelephony communications (2007)

ICAO Assembly Resolution A37-10, Proficiency in the English language used for radiotelephony communications (2010)

ICAO Assembly Resolution A38/8 - Proficiency in the English language used for radiotelephony communications (2013)

Annex 1 to the Convention on International Civil Aviation. Personnel Licensing, Eleventh Edition, ICAO, July 2011

Annex 10 to the Convention on International Civil Aviation, Aeronautical Telecommunications, Vol. 2. Communication Procedures including those with PANS status

Manual on the Implementation of ICAO Language Proficiency Requirements, ICAO Doc $9835 \mathrm{AN} / 4532004$

ICAO Journal, Issue 5 (2013)

\section{The EU legal sources:}

Treaty on the Functioning of the European Union, OJ C 326, 26.10.2012

Directive 2006/23/EC of the European Parliament and of the Council of 5 April 2006 on a Community air traffic controller licence, OJ L 114, 27.4.2006 
Regulation (EC) No 216/2008 of the European Parliament and of the Council of 20 February 2008 on common rules in the field of civil aviation and establishing a European Aviation Safety Agency, and repealing Council Directive 91/670/EEC, Regulation (EC) No 1592/2002 and Directive 2004/36/EC, OJ L 79, 19.3.2008

Commission Regulation (EU) 1178/2011 laying down technical requirements and administrative procedures related to civil aviation aircrew pursuant to Regulation (EC) No 216/2008 of the European Parliament and of the Council, OJ L 311, 25.11.2011

Commission Regulation (EU) 2015/445 of 17 March 2015 amending Regulation (EU) No 1178/2011 as regards technical requirements and administrative procedures related to civil aviation aircrew, OJ L 74, 18.3.2015

\section{The Polish legal sources:}

Rozporządzenie Ministra Transportu, Budownictwa i Gospodarki Morskiej z dnia 2 września 2013 r. w sprawie licencjonowania personelu lotniczego (Dz. U. 2013 poz. 1077) [Regulation of the Minister of Transportation, Construction and Maritime Economy on the aviation personnel licensing of 2013 (Official Journal of the Republic of Poland 2013, item 1077)]

Zarządzenie nr 5 Prezesa Urzędu Lotnictwa Cywilnego z dnia 21 stycznia 2008 roku w sprawie wprowadzenia do stosowania Procedury obiegu dokumentów przy wydawaniu lub odmowie wydania licencji z uprawnieniem do przeprowadzania korespondencji radiotelefonicznej w języku angielskim, wpisania lub odmowy wpisania uprawnienia do przeprowadzania korespondencji radiotelefonicznej w języku angielskim albo potwierdzenia lub odmowy potwierdzenia biegłości języka angielskiego na poziomie wymaganym przez Załącznik nr 1 do Konwencji o międzynarodowym lotnictwie cywilnym (Dziennik Urzędowy Urzędu Lotnictwa Cywilnego z dnia 16 maja 2008 r., nr 5, poz. 45) [Decree nr 5 of the President of the Civil Aviation Authority of January 21, 2008 on the application of the Procedure for documents' circulation for the issuing or rejection of issuing of the license with entitlement to carry out radiophonic communication in English, on noting or rejection of noting the entitlement to carry radiophonic communication in English or on confirmation or rejection of confirmation of the English language fluency on the level required by the Annex 1 to the Convention on International Civil Aviation (Official Journal of the Civil Aviation Authority, May 16 2008, no 5, item 45)]

The U.S. legal sources:

Pilot-Controller Communication Errors: An Analysis of Aviation Safety Reporting System (ASRS) Reports, US Department of Transportation, Federal Aviation Administration, Final Report, August 1998 